\title{
Life in New Icaria, lowa: A Nineteenth Century Utopian Community
}

\author{
Boris Blick \\ H. Roger Grant
}

OF THE MANY ACTIVE UTOPIAN movements in the United States during the nineteenth century, the French Icarians stand out. The Icarians came to America to realize the happy, harmonious communist society outlined by their founder Etienne Cabet ${ }^{1}$ (1788-1856), in his famous utopian novel, Voyage en Icarie ${ }^{2}$ (1839). In this utopian romance, as in his other works, Cabet stressed the fundamental socialist view that an unjust, and irrational, competitive social order was the source of man's unhappiness. The abolition of inequality and private property and the institution of a totally regulated communist utopia, based on his own detailed blueprint would, he was certain, produce the secular "Garden of Eden."

For half a century, from 1848 to 1898 , nearly two thousand French communitarians (although never numbering more than five hundred at any one time) tried to reach the Icarian utopia, first in Texas, later in Illinois, Missouri, and lowa, and finally in California. ${ }^{3}$

\footnotetext{
${ }^{1}$ The leading studies of Étienne Cabet are Jules Prudhommeaux, Icarie et son fondateur, Étienne Cabet: Contribution d̀ l'étude de socialisme expérimental (Paris: Édouard Cornély \& Cie., 1907) and Sylvestor A. Piotrowski, Étienne Cabet and the Voyage en Icarie: A Study in the History of Social Thought (Washington, D.C.: The Catholic University of America, 1935).

${ }^{2}$ This novel originally appeared as Voyage et aventures de Lord William Carisdall en Icarie, Ouvrage traduit de I'anglais de Francis Adams (Paris: Hippolyte Souverain, 1839). In 1840, however, it was republished as Voyage en Icarie.

${ }^{3}$ Specifically the Icarian communities were as follows: Red River, Texas, 1848 (3 months); Nauvoo, Illinois, 1849-1860; Cheltenham, Missouri, 1858-1864; Adams County, lowa, 1852-1878; Jeune Icarie, Iowa, 1878-1886; New Icaria, lowa, 1878-1898; and Icaria Speranza, California, 1881-1886.
} 


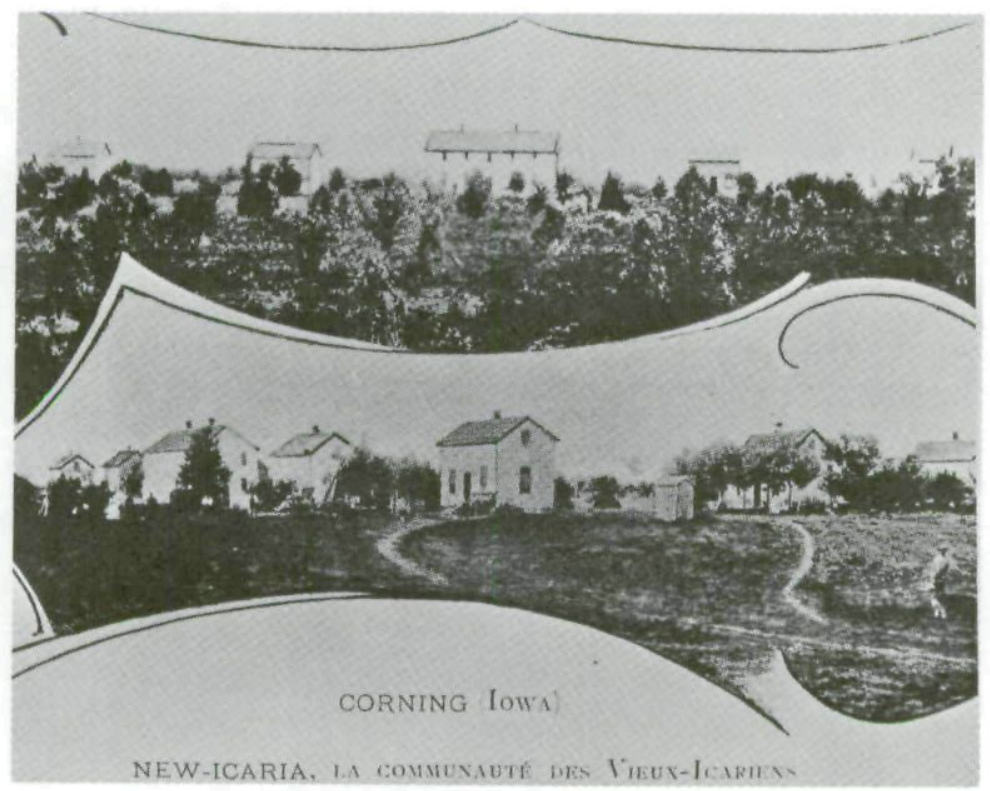

\section{Courtesy of Authors \\ Views of the town of New Icaria (Corning, lowa) around 1886.}

The Icarian experience looms large in the history of American utopian communes, partly for its greater duration and numbers, and because its history was so representative of nineteenth century American utopianism. A response to hard times, rapid change and industrialization in early nineteenth century France, the Icarian movement took root in the open spaces of the American frontier.

The general subject of the Icarians in the United States is treated in Albert Shaw, Icaria: A Chapter in the History of Communism (New York: Putnam's 1884); Adolph Hepner, Die Ikarier in Nordamerika: Eine Warnung vor Communistischen Colonialgründungen (New York: Gedruckt bei J. Oehler, 1886); Morris Hillquit, History of Socialism in the United States (Funk, 1906); Prudhommeaux, Icarie et son fondateur, Etienne Cabet; Will Alfred Hinds, American Communities and Cooperative Colonies, 2nd ed., rev. (Chicago: Charles H. Kerr \& Co., 1908); Charles Gide, Communist and Co-operative Colonies, trans. Ernest F. Row (London: George G. Harrap and Co., Ltd., 1930); Robert V. Hine, California's Utopian Colonies (1953; rpt. New Haven: Yale University Press, 1966); and H. Roger Grant, "Icarians and American Utopianism," Illinois Quarterly, 34 (February, 1972), pp. 5-15. 
Like most American utopian ventures, it was inspired by a "prophet" who provided its essential conceptions and philosophy. And more significantly, the perennial problems and conflicts-the opposition of individualism and collectivism, the disagreement over political authority, the beckoning economic opportunities outside the pale of utopia, and ultimate failure-place the Icarians in the mainstream of nineteenth century utopianism.

Although the Icarian colony at Nauvoo, Illinois, ${ }^{4}$ because of its size and Cabet's presence overshadowed other Icarian settlements; the lowa phase was important. For two generations, from 1852 until 1898, Icarians lived east of Corning in Adams County. Initially the lowa colony was a branch of the parent Nauvoo settlement. But when a bitter conflict over Cabet's dictatorial authority ended in the expulsion of Cabet and his devoted followers in 1856, ${ }^{5}$ their opponents liquidated their holdings and by 1860 had moved to lowa. There, after much work and hardship, they realized a modest prosperity. Membership, however, remained small, rarely more than seventy-five and usually fewer. In the mid-1870s factional controversy flared-up and in 1878 the community split. A group of young, idealistic revolutionaries, some having experienced the Paris Commune (1871) and some swayed by Marxism, denounced the private property which had crept in or had been tolerated by the community (Cabet's ideal utopia totally excluded all forms of private property). They also demanded the abolition of the community's presidency to be replaced by an executive of four annually elected trustees. The "radicals" gained control of the village and the "conservatives," mostly older people opposed to drastic change, moved a few miles south. There, with their share of the colony's assets, they built "New Icaria." The "radicals," calling their settlement "Jeune Icaria," ("Young Icaria") also founded a community in northern California, "Icaria Speranza." Both ventures failed in 1886, leaving only the older group to carry on the Icarian tradition.

While studies of the lowa Icarians have been published (the most

\footnotetext{
${ }^{4}$ For an overview of the Icarian experience at Nauvoo, Illinois see $\mathrm{H}$. Roger Grant, ed., An Icarian Communist in Nauvoo: Commentary by Emile Vallet (Springfield: Illinois State Historical Society, 1971).

${ }^{5}$ Cabet and his followers moved to St. Louis, Missouri. Although Cabet died shortly after arriving there, his followers by 1858 built the Cheltenham colony, some six miles from the city, which lasted until 1864 .
} 
recent being Lyman Tower Sargent's "The Icarians in lowa," which appeared in the Spring 1972 issue of the Annals of (owa), ${ }^{6}$ little has been written on Icarianism after the falling-out of 1878.? The following passage, translated from New Icaria's French-language newspaper, Revue Icarienne, ${ }^{8}$ of March-April 1885, describes everyday life in the colony. ${ }^{9}$ Contemporary evidence appears to bear out the accuracy of this "all-is-going-well" account.

\section{News of Icaria}

Since our last No [sic] we have no new developments to bring to the attention of our readers, but it strikes us that it would be interesting for them to know what is our way of life and what is our routine. ${ }^{10}$

We are therefore going to try to tell you about our daily occupation and what our food, housing and clothing consists of.

We will tell you first of all, that as each member must devote all of his time to the Community and produce for it all within his power, everybody works according to his strength and his ability ${ }^{11}$

'For the lowa colonies see S. W. Huff, "Icaria," Annals of lowa, ser. 1, 5 (April, 1867), pp. 848-853; Barthinius L. Wick, "The Icarian CommunityStory of Étienne Cabęt's Experiment in Communism," The Midland Monthly, 3 (April, 1895), pp. 370-376; Charles Gray, "The Icarian Community," Annals of lowa, ser., 3,6 (July, 1903), pp. 107-114; Ruth A. Gallaher, "Icaria and the Icarians," The Palimpsest, 2 (April, 1921), pp. 97-112; Maude M. Friman, "The History of the Icarian Colony (Adams County)," 1942, typed copy in the Library of the State Historical Society of lowa, lowa City; Martha Browning Smith, "The Story of Icaria," Annals of Iowa, ser. 3, 38 (Summer, 1965), pp. 38-62; and Lyman Tower Sargent, "The Icarians in lowa," ibid., ser. 3, 41 (Spring, 1972), pp. 957-968.

'Marie Marchand Ross's Child of Icaria (New York: City Publishing Co., 1938 ) provides colorful detail of life in Icarian lowa.

${ }^{8}$ Surprisingly, those who have examined the lowa phase of Icarianism have failed to use its two newspapers, which were published after the 1878 division. Both the New York Public Library and the Bibliotheque Nationale in Paris have holdings of the Revue Icarienne (New Icaria) and La jeune Icaria (Jeune Icaria).

${ }^{9}$ In translating this excerpt from the Revue Icarienne care has been taken to remain faithful as English usage permits to the style and idiosyncrasies of the original French.

${ }^{10}$ In the surviving issues of the Revue /carienne one finds few references to the affairs of the community. Excerpts from Cabet's works, French and European revolutionary politics, abstract essays on socialism and criticism of capitalist society predominate. Possibly the editor inserted this description of New Icaria as "filler."

${ }^{11}$ The Icarian population in lowa, as indicated in the introduction, was small. In January 1882 the Revue Icarienne reported that the New Icaria 
- The oldest are entrusted with the most sedentary work, they keep themselves busy, some making wood for the kitchen, others are entrusted with the care of the horses, livestock [,] and pigs, one is entrusted with the gardening, another with the cooking and the baking of bread; the youngest do the heaviest farming work and all the necessary cartage for the Community such as the transport of wood from the forest to the village during the winter and the transport of our produce to the nearest railway depot. ${ }^{12}$

We have about 300 acres under cultivation, we intend to clear 80 acres more this year, so that we can produce more corn, which is our principal crop, that which will allow us to raise a greater number of horses, oxen [,] and pigs. - Note that our Community is mainly agricultural.

The women and the young girls are entrusted with the making and the upkeep of the clothing of all the members, in addition to the washing. They also help prepare the yegetables for cooking, wash the dishes and set the table for all the meals. The children go to school and the oldest help as much as they can either with the waiting on tables or the sewing, etc.

Consequently all work according to their strength and ability.

Here now is what our food consists of. We serve three meals a day, breakfast at six in the morning, dinner at noon and supper at six in the evening; in the winter supper is served earlier and in the summer later.

At breakfast we have vegetable soup, coffee with milk, butter or cheese and often eggs. At dinner, a dish of meat and one or two dishes of vegetables, in the summer [,] salad, cream cheese and frequently fruit for dessert or honey, molasses or jams - At supper, soup, a dish of vegetables, stewed apples or jams, and in summer cream cheese. For beverage at dinner and supper, milk for those who want it and unlimited supply of very wholesome water. On holidays $^{13}$ we have been indulging ourselves with wine since our

colony consisted of nine men (average age 42), twelve women (average age 52), and twelve children.

${ }_{12}$ The nearest railroad station was located in Corning, four miles west of the settlement, on the Burlington and Missouri River Railroad (later the Chicago, Burlington and Quincy and now the Burlington Northern).

${ }^{13}$ Since the Icarians did not observe traditional religious and American national holidays, they celebrated instead January 1st, Cabet's birthday; February 3rd, commemoration of the first Icarian "departure" for the United States; and July 14th, Bastille Day. Possibly events of local significance may have been remembered. 
vineyard has begun to produce. We haven't yet harvested the apples from our orchard, because it is too young, but it promises us some for later on, then perhaps we will be able to make some cider and enjoy some.

Our food is wholesome and plentiful without being dainty and elaborate [,] but we have the best of cooks, ... [and] the appetite which comes from working in pure country air.

As for housing in our Community, each family has a separate house, composed of four rooms ${ }^{14}$-Our old people who are widowed or single have each a room over the refectory - Every house is surrounded by a small garden where every family raises flowers.

The common house where the refectory and the kitchen are at the ground level has six rooms on the second floor which are occupied as stated above and below the whole house a good stone cellar where we can keep our store of vegetables during the winter and where we have ample space for our wine, when our vineyard will be in full production. All the houses are well heated during the winter and well ventilated in the summer.

Every house is furnished as comfortably as possible; good beds and good bedding-tables and chairs and cupboards to stow belongings.

Our clothes are similar to those of all the well-off farmers of the region where we live - We have winter clothing and summer clothing, work clothing and holiday clothing - We have no special dress, but we are all decently dressed, without luxury and without overdoing. Our womenfolk are dressed simply but very proper.

From the preceding, our readers can see that from the material point of view we don't lack anything, and it could be wished that everywhere the working class can enjoy the same advantages. Among us the most scrupulous equality [prevails] in everything.

\footnotetext{
${ }^{14}$ As Professor Sargent and others have noted, the Icarians did not regard marriage and the family as incompatible with their collectivity. Cabet's insistence upon marriage and the traditional family structure conformed to the opinion of the majority of nineteenth century utopians. Cabet wrote: "Since marriage and the family are the chief condition of happiness for men, for women, especially, and for children, the social organization is so prepared that all Icarians may be able to marry and have families." (Étienne Cabet, "History and Constitution of the Icarian Community," trans. Thomas Teakle, lowa Journal of History and Politics, 15 (April, 1917), p. 241.)
} 


$$
\text { \# \# }
$$

New Icaria quietly passed away in 1898. At the time of dissolution, only twenty-one members remained. They divided the colony's assets, which included "sufficient property to place all in fairly comfortable circumstances." New Icaria, wrote historian Charles Gide, "died neither of poverty nor strife, but simply of old age. The faithful had grown old, and the younger generation had not come along." 15

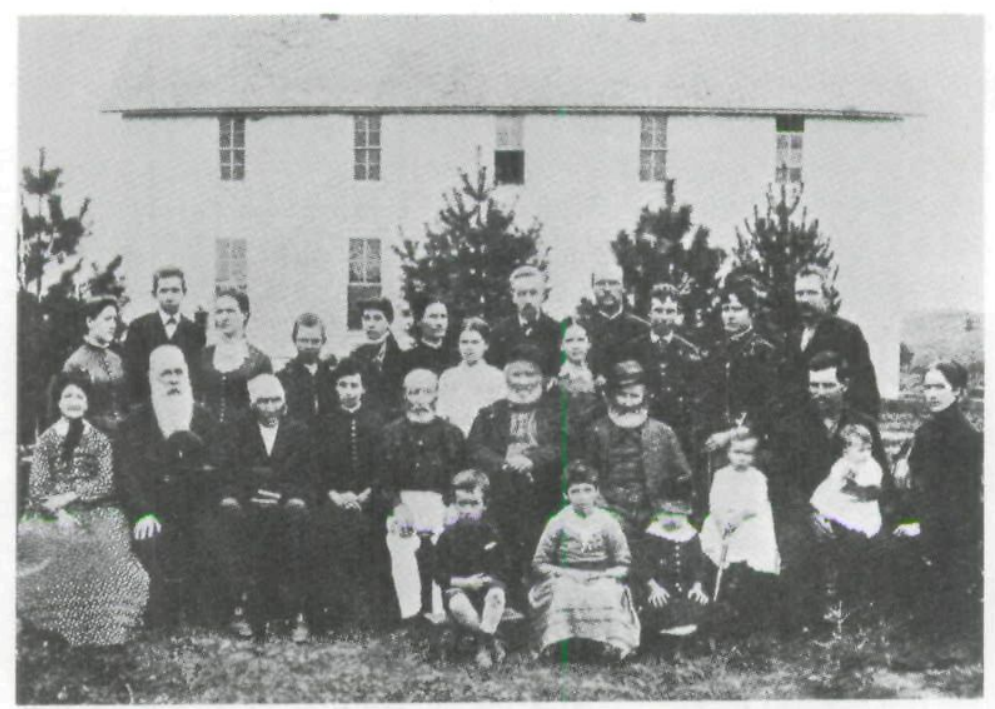

Courtesy of Authors

Inhabitants of New Icaria, lowa, circa 1886.

${ }^{15}$ Gide, Communist and Co-operative Colonies, pp. 147-148. 
Copyright of Annals of Iowa is the property of State of Iowa, by \& through the State Historical Society of Iowa and its content may not be copied or emailed to multiple sites or posted to a listserv without the copyright holder's express written permission. However, users may print, download, or email articles for individual use. 